\title{
Diaphragmatic hernia and rib fractures in an adult horse with signs of colic
}

\author{
Marie Zusatz ${ }^{1}$, Christophe Desbois², Céline Robert ${ }^{3}$ and Bianca Carstanjen ${ }^{1}$ \\ Clinique Equine', Unité de Chirurgie ${ }^{2}$ and Unité d'Anatomie ${ }^{3}$, Ecole Nationale Vétérinaire d'Alfort, Maisons-Alfort, France
}

\begin{abstract}
Summary
The following case report describes a diaphragmatic hernia and rib fractures in an adult horse with signs of recurrent colic. A 13 -year-old Standardbred gelding was referred to the emergency duty for abdominal pain. The horse was subjected to explorative laparotomy, which revealed a right displacement of the colon, an impaction of the transverse colon and a retroflexion of the cecum. Necropsy revealed a diaphragmatic hernia (approximately two centimetres in diameter) in the left mid-region with the greater omentum adherent to the seventh and eighth ribs, the pleura and to the pericardium. A prior external trauma during a riding accident was thought to be the cause of the described rib fractures.
\end{abstract}

Keywords: diaphragmatic hernia, rib fracture, colic, exercise intolerance.

\section{Zwerchfellhernie und Rippenfrakturen bei einem Pferd mit Kolik}

Im vorliegenden Fallbericht wird ein Pferd mit Zwerchfellhernie und Rippenfrakturen beschrieben. Ein 13-iähriger Traberwallach wurde dem Notfalldienst wegen Kolik überwiesen. Eine Probelaparotomie ergab eine Rechtsverlagerung des Kolon, eine Anschoppung im Bereich des Colon transversum und eine Retroflexion des Zäkum. Die pathologische Untersuchung ergab eine Zwerchfellhernie (von ungefähr zwei Zentimeter Durchmesser) in der linken mittleren Region, mit Verklebungen zwischen großem Netz und siebter und achter Rippe, Pleura und Perikard. Als vermutete Ursache für die beschriebenen Rippenfrakturen wurde ein vorangegangenes äußeres Trauma bedingt durch einen Reitunfall angenommen.

Schlüsselwörter: Zwerchfellshernie, Rippenfraktur, Kolik, Belastungsintoleranz

A 13-year-old Standardbred gelding was referred for colic to the emergency duty of the National Veterinary School of Alfort, France. A riding accident with a fall on the left side had occurred one year before. The horse had a history of mild colic and exercise intolerance, which were concomitant with the horse's transfer from pasture to stalling six months ago. The episodes of colic occurred mainly after exercise, and the horse responded to the administration of dipyrone and flunixin meglumine. Previously performed blood and peritoneal fluid analysis, rectal examination, gastroscopy, coprology and oral glucose absorption test were within normal limits. At admission at the emergency duty the horse was in moderate body condition (510 kg body weight), with normal clinical parameters. The thorax showed a slight depression at the left seventh and eighth rib, but no signs of thoracic pain were present. Clinical examination showed depression, and abdominal pain (ie, rolling, restlessness). There was no nasogastric reflux present. Abdominal auscultation revealed tympanic sounds in the right dorsal quadrant and percussion revealed a high-pitched "ping» over the cecum. Trans-rectal examination was consistent with cecal distension, a right displacement of the pelvic flexure and firm feces in the small colon. Haematology and blood biochemistry were within nor- mal limits. Based on the transrectal examination and physical examination findings, exploratory laparotomy was pursued. The horse received procaine penicilline (Depocilline ${ }^{\circledR}$, Intervet, Beaucouze, France; $22000 \mathrm{IE} / \mathrm{kg}, \mathrm{IM})$, gentamycin (G4 ${ }^{\circledR}$, Virbac, Carros, France; $6,6 \mathrm{mg} / \mathrm{kg}, \mathrm{IV}$ ) and flunixin meglumine (Finadyne ${ }^{\circledR}$, Schering-Plough Vétérinaire, Levallois-Perret, France; $1,1 \mathrm{mg} / \mathrm{kg}$, IV) 30 minutes prior to general anesthesia. Premedication was performed using detomidine (Domosedan ${ }^{\circledR}$, Pfizer, Paris, France; $0,02 \mathrm{mg} / \mathrm{kg}$, IV) five minutes prior to induction. General anesthesia was induced with diazepam (Valium ${ }^{\circledR}$ Roche, Neuilly-sur-Seine, France; $0,05 \mathrm{mg} / \mathrm{kg}, \mathrm{IV}$ ) and ketamine (Imalgène 1000 ${ }^{\circledR}$, Merial, Lyon, France; 2,2 mg/kg, IV) and maintained with halothane (Halothane Vétérinaire Belamont ${ }^{\circledR}$, Belamont, Boulogne-Billancourt, France) in 100\% oxygen. The horse was placed in dorsal recumbency and the abdomen was prepared aseptically for ventral midline celiotomy.

Ventral midline laparotomy revealed a thickened and fibrous peritoneum with fibrous tags. A right dorsal displacement of the colon was present with an impaction of the transverse and right dorsal colon. The apex of the cecum was retroflexed and the distal segment of the ileum hypertrophied. Jejunum, duo- 
denum and stomach were normal. Besides an irregular peritoneal surface and tags of the serosa of the right dorsal colon, no distension or incarcerations were palpated. An enterotomy of the pelvic flexure was performed, to evacuate the accumulated digesta of the transverse as well as of the right and left colon. The enterotomy incision was closed with a two layer suture pattern (i.e. simple continuous suture and Cushing suture pattern) using 2/0 USP monofilament glycomer 631 (Biosyn ${ }^{\circledR}$, Vétoquinol S.A., Paris, France). Full thikkness intestinal biopsies were taken at the pelvic flexure, hypertrophied ileum and cecum. The biopsy sites were sutured with a two layer suture pattern as above described. The intestinal structures were put in place and the linea alba was closed with an interrupted inversed Sultan suture pattern using double 2 USP polyglactin 910 (Polysorb ${ }^{\circledR}$, Vétoquinol S.A., Paris, France). The subcutaneous tissue was closed with a simple continuous suture pattern using 2/0 USP monofilament glycomer 631 (Biosyn ${ }^{\circledR}$, Vétoquinol S.A., Paris, France). Skin closure was performed with skin staples (3M PreciseTMVista, 3M Santé, Cergy-Pontoise, France) and the surgical site was protected with a sterile wound dressing. The horse had a prolonged recovery from general anesthesia and fell heavily when trying to stand up. A respiratory and cardiovascular distress was noted and the horse subsequently died.

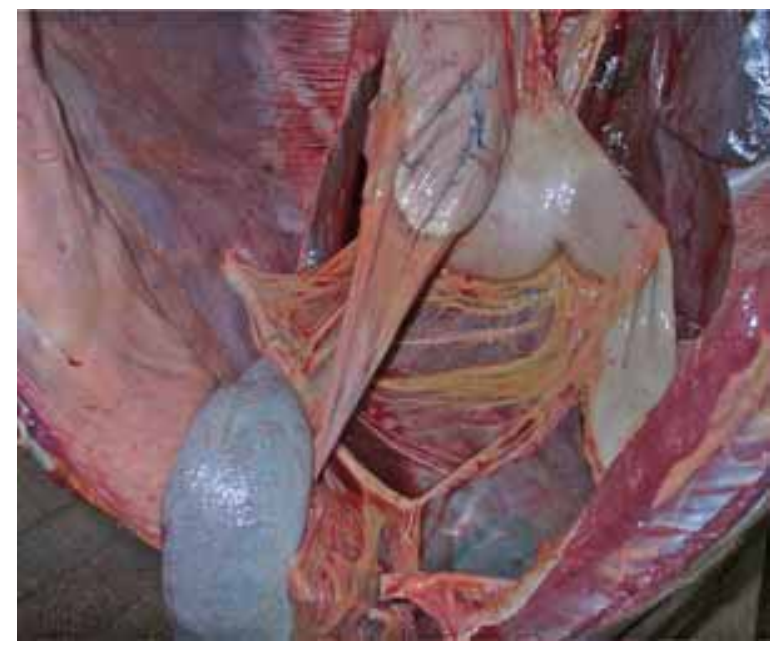

Fig 1 A $2 \mathrm{~cm}$ defect in the left middle aspect of the diaphragm resulted in herniation of the greater omentum into the thorax. Ein $2 \mathrm{~cm}$ großer Defekt im mittleren Bereich des Zwerchfells führte zu einem Vorfall des großen Netzes in die Brusthöhle.

Necropsy revealed fibrin accumulation between body wall and the right dorsal colon. The ileum was hypertrophied and showed signs of inflammation. A diaphragmatic defect, approximately two centimetres in diameter, occupied a left middle position adjacent to the eighth rib (Fig 1). A part of the greater omentum was adherent to the rent and entered the left thoracic cavity. This part was in continuity with the gastro-splenic ligament (Fig 1). This intrathoracic part of the omentum was adjacent to the pericardium and adherent to the fractured seventh and eighth ribs, which were stabilized with callus formation (Fig 2). Furthermore adhesions between fractured ribs and pleura were present (Fig 2 and 3). The cranial lobe of the left lung was atelectatic. The left femur showed a closed, displaced, spiral fracture. A vast haematoma was present expanding from the left fractured femur through the pelvis to the bladder.
Histological examination of intestinal biopsies revealed eosinophilic enteritis possibly due to worm infestation. Moreover, histological examination of lung and kidney were normal.

Diaphragmatic hernias are uncommon in horses, and can be of two types: congenital in the foal and acquired in the adult (Collobert-Laugier and Tariel 1988). Diaphragmatic rupture can be caused by increased intra-abdominal pressure (e.g. horses subjected to severe exercise, pregnant and post-parturient mares) or by external trauma (Roelvink et al 1993). Clinical signs include weight loss, exercise intolerance, and variable degrees of abdominal pain, which often depend on the nature and amount of intestinal segment involved in the defect (Corley and Bertone 1990). Although radiography and ultrasonography may aid in the diagnosis, most diaphragmatic hernias are diagnosed during laparotomy or necropsy.

Traumatic rupture of the diaphragm occurs following to blunt trauma or penetrating injuries to the abdomen and chest (Collier 1999). Rare cases of diaphragmatic hernia due to fractured ribs are reported in adults (Ethell et al. 1999). In contrast, fractured ribs are more common in newborn foals than in adult horses, and can occur during gestation or par-

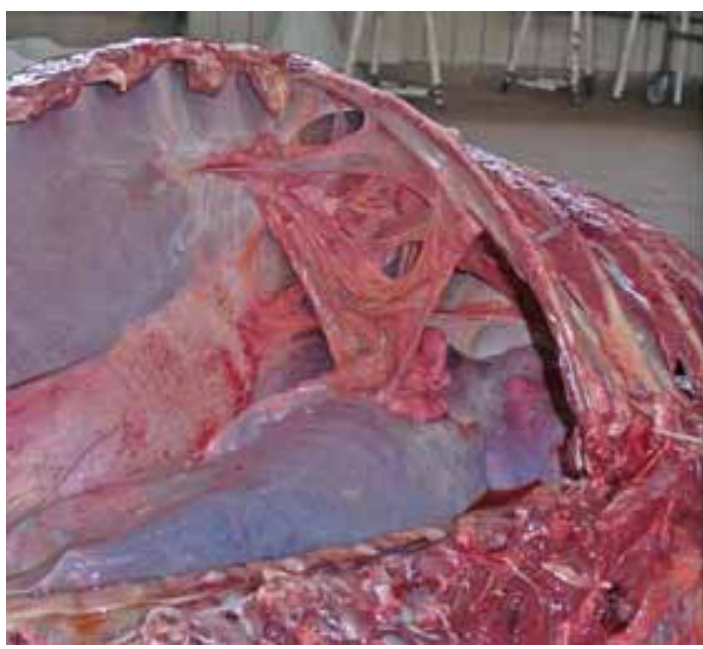

Fig 2 Necropsy finding of the thorax (caudal view). The greater omentum herniated through the tear in the diaphragm and adhered to the callus of the fractured ribs and pericard.

Pathologischer Befund am Thorax (von kaudal). Das große Netz fiel durch den Zwerchfellriss vor und verklebte mit Kallus der frakturierten Rippen und Perikard.

turition. Ribs three to eight account for the majority of injuries (Schambourg et al. 2003). In adult horses, rib fractures can incriminate an old traumatic incident (Firth 1976; Roelvink et al. 1993). A fall can be a cause of increased intra-abdominal pressure (Firth 1976). In the above described case, the thoracic trauma could have occurred during a high speed riding accident. The time interval between the above described riding accident and clinical symptoms might be due to the fact that herniation through the defect can occur immediately or months even years after the traumatic event (Collier 1999).

The position of the diaphragmatic defect is related to the type of hernia. Post-mortem ruptures are seen in the ventral diaphragm, congenital defects in the dorsal portion and trauma- 
tic defects occur most frequently in the middle portion of the diaphragm (Proudman and Edwards 1992). In the above case, the position of the rent is in the middle part of the diaphragm. Organs reported to herniate include small intestine, stomach, liver, large and small colon, spleen, cecum and omentum (Everett et al. 1992; Edwards 1993). Clinical signs of diaphragmatic hernias are variable (Steenhaut and Verschooten 1996) and are usually related to the portion and amount of intestine herniated. In case of small defects, only small intestine can herniate and clinical signs frequently include acute abdominal pain. In case of a large defect the colon herniates and the horse presents chronic and intermittent colic (Everett et al 1992; Edwards 1993). Auscultation of the abdomen may reveal an absence of intestinal borborygmy and rectal palpation is inconsistent in diaphragmatic hernias (Corley and Bertone 1990). In the case described, only the greater omentum has herniated; there was no intestine in the rent. Moderate recurrent signs of colic are explained by the omental herniation and adhesions between rib, pleura and pericardium.

Although dyspnea is rarely the most evident sign of diaphragmatic hernia in the horse (Corley and Bertone 1990) diaphragmatic hernia is described to be the cause of lethargy and exercise intolerance (Everett et al. 1992). This can be

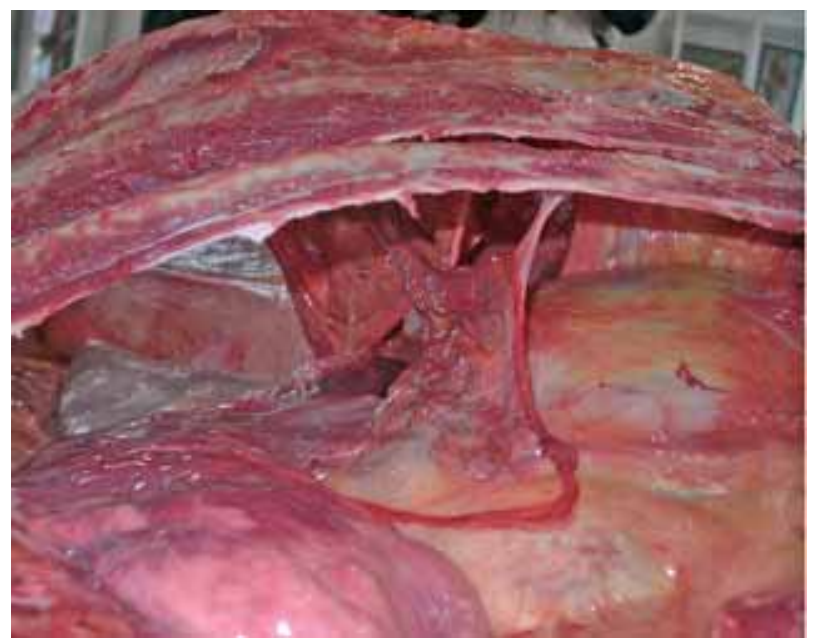

Fig 3 Necropsy finding of the thorax (cranial view). Adhesions between greater omentum, ribs and pericard.

Pathologischer Befund am Thorax (kraniale Ansicht). Adhäsionen zwischen großem Netz, Rippen und Perikard.

explained by the fact that, in the horse in motion, compression of the lung by the diaphragm is an important part of the expiratory phase of respiration (Collier 1999). Therefore, when there is a tear in the diaphragm, the compression of the lung is compromised, the expiratory phase is interrupted and the horse cannot sustain physical effort.

The recurrent colic is due to traction on visceral organs consecutive to adhesions. Loss of body-condition, as observed in the above case, can also be a part of the clinical signs, and together with exercise intolerance, is often one of the first signs noted by the owner (Kaneps 1992; Edwards 1993).

Long bone fractures during recovery from anesthesia are a well described complication in the equine species (Serteyn 2003). The reported case is an exercise restricted adult horse with poor body condition, poor performance, continuous systemic non-steroidal-drug administration and recurrent symptoms of pain. Based on these facts, decreased bone density and strength might have been the reason for a higher fracture-risk compared to young healthy subjects (Bernstein and Leslie 2003). The cardiovascular and respiratory depression after the fall in the recovery box and the horse's death might be explained by the diaphragmatic hernia, severe pain and exhaustion, or might also be explained by the abundant internal haemorrhage due to the femoral fracture. The role of the hernia in the death of the horse is difficult to define exactly because there was no intestine displaced through the rent, and there was no real communication between thoracic and abdominal cavity.

In summary, diaphragmatic hernias are uncommon in horses and should always be considered in the differential diagnosis of recurrent colic. The diagnosis is made with clinical signs and can be confirmed intra-operatively. Palpation of the diaphragm is advised to a part of any exploratory laparotomy.

\section{Literature}

Bernstein C. N. and W. D. Leslie (2003): The pathophysiology of bone disease in gastrointestinal disease. Eur. J. Gastroenterol. Hepatol. 15, 857-864

Collobert-Laugier C. and G. Tariel (1988): Deux cas de rupture du diaphragme dans l'espèce équine. Le Point Vét. 19, 723-725

Corley J. R. und A. Bertone (1990): Diaphragmatic hernia in a horse. Equine Pract. 12, 28-31

Dieckmann M., E. Deegen and H. J. Klein (1989): Zwerchfellhernie bei einem 14-jährigen Islandpferd. Pferdeheilkunde 5, 263-265

Edwards G. B. (1993): Diaphragmatic hernia: a diagnostic and surgical challenge. Equine Vet. Educ. 5, 267-269

Ethell M. E., J. P. Graham and C. D. Buergelt (1999): What's your diagnosis? J. Am. Vet. Med. Assoc. 215, 321-322

Everett K. A., M. K. Chaffin and S. P. Brinsko (1992): Diaphragmatic herniation as a cause of lethargy and exercise intolerance in a mare. Cornell Vet. 82, 217-223

Firth E. C. (1976): Diaphragmatic hernia in horses. Cornell Vet. 66, 353-361

Kaneps A. J. (1992): Hernias. In: Auer J. A., ed. Equine surgery. 1 st ed. Philadelphia: WB Saunders Co, 415-422

Proudman C. J. and G. B. Edwards (1992): Diaphragmatic diverticulum in a horse. Equine Vet. J. 24, 244-246

Roelvink M. E., M. M. Sloet Van Oldruitenborgh-Oosterbaan and $H$. C. Kalsbeek (1993): Chronic diaphragmatic hernia in the horse. Equine Vet. Educ. 5, 255-258

Schambourg M. A., S. Laverty, S. Mullim, U. M. Fogarty and J. Halley (2003): Thoracic trauma in foals: post mortem findings. Equine Vet. J. 35, $78-81$

Serteyn D. (2003): Les complications de l'anesthésie générale chez le cheval. Prat. Vét. Equine 35, 17-23

Collier D. (1999): Comparative aspects of diaphragmatic hernias. Equine Vet. J. 31, 358-359

Steenhaut M. and F. Verschooten (1996): Diaphragmatic hernia in the horse. Vet. Annu. 36, 256-263

\section{Dr. Bianca Carstanjen PhD}

Clinique Equine; Ecole Nationale Vétérinaire d'Alfort

7. Avenue du Général de Gaulle 94704 Maisons-Alfort, Cedex; France bcarstanjen@vet-alfort.fr 